\title{
Maintenance of Ephedra alata Seeds Viability via Storage Containers
}

\author{
Abdulaziz A. Al-Qarawi, Elsayed F. Abd_Allah* \\ ${ }^{1}$ Plant Production Department, College of Food \& Agriculture Sciences, King Saud University, Riyadh, Saudi Arabia. \\ Email: *eabdallah@ksu.edu.sa \\ Received October 22 $2^{\text {nd }}, 2010$; revised November $19^{\text {th }}, 2010$; accepted November $22^{\text {nd }}, 2010$.

\begin{abstract}
Sequential incubation of seed samples yielded 20 fungal species belonging to 13 genera. The prevalent genera were Aspergillus (A. flavus and A. parasiticus), Fusarium (F. moniliforme and F. oxysporum) and Penicillium (Penicillium sp.). Such seedborne fungi differ in their colonization in different parts of seeds with most of them are colonized in seed coat, endosperm, and embryo of the seed. The usage of different storage containers for storing seeds indicated that the cotton cloth bags were the most favorable ones as they maintain seed moisture content (SMC) below the critical level resulting in minimum seed deterioration compared with other seed storage containers.
\end{abstract}

Keywords: Seedborne Fungi, Ephedra alata, Storage Containers, Saudi Arabia

\section{Introduction}

Ephedra alata Decne, a gymnosperm belong to family Ephedraceae, is one of the oldest range and medicinal herb known in Saudi Arabia as well as in different rangelands in the world [5]. It was noted as it is accompanied with sand dunes formation in Saudi Arabia especially the mobile ones and therefore it is a very effective sand-binder and resistant to desertification [3]. The foliage of E. alata have acceptable aroma and used as foodstuff for animals especially camels, cattle and sheep. The deterioration of plant community had occurred in Saudi Desert due to abiotic factors such as soil salinity [7], edaphic factors of the soil [29] and soil drought [6]. On other hand, the biotic stresses such as seedborne fungi play an important and vital role in deterioration of seed quality $[1,2]$. Seedborne fungi use different mechanisms to deteriorate seeds such as production of both mycotoxins [2] and enzymes [26] which have attracted much attention of our investigations.

Application of prophylactic fungicides is not the preferred choice in range seeds especially in the sheltered areas. This raised the need to study safe alternative strategies to control seedborne fungi that attack range plants and might be transmitted to the aerial parts of the plants [4]. Seed storage containers play an important and considerable role in the production of healthy and vital seeds $[21,25 ; 27]$. The successfulness of the storage containers restricted with surrounding factors such as seed nature, storage period, temperature, relative humidity, and seed moisture content. Consequently, the production of healthy and vital range seeds should managed through integrated approach.

The present study was designed to investigate the seedborne fungal flora of $E$. alata with special reference to their incidence in different seed parts. Furthermore, the effect of different storage containers on seed moisture content (SMC), seed vigor (SV), aflatoxins accumulation, and nutritional value of storage seeds (E. alata) was studied.

\section{Materials and Methods}

\subsection{Seed Samples Collection}

Seed samples of Ephedra alata Decne (approximately $100 \mathrm{~g}$ seeds per sample, each in replicates) were collected from King Khalid Center for Wildlife Research and Development at Thumama which belonging to Riyadh Region, Saudi Arabia during 2009. The samples were collected in sterile cellophane bags and held at $2^{\circ} \mathrm{C}$ until analyzed according to the International Seed Testing Association [20].

\subsection{Enumeration of Seedborne Fungi}

From each seed sample, 400 seeds were surface-disinfected in Na-hypochlorite for two minutes followed washing with several changes of sterile saline water (8.5 gm $\mathrm{NaCl}$ in $1000 \mathrm{ml}$ distilled $\mathrm{H}_{2} \mathrm{O}$ ). The disinfected 
seeds were then incubated aseptically on potato dextrose agar (PDA, Difco Laboratories, Detriot MI). Rose Bengal $(33 \mathrm{mg} / \mathrm{ml}, \mathrm{w} / \mathrm{v})$ and Streptomycin $(30 \mathrm{mg} / \mathrm{ml}, \mathrm{w} / \mathrm{v})$ were added as bacteriostatic agents. Surface-disinfected seeds were spaced on Petri dishes ( $9 \mathrm{~cm}$ in diameter) and incubated at $28 \pm 2{ }^{\circ} \mathrm{C}$ for 10 days. Similarly, surface-disinfected seeds were incubated on sterile moist filter paper with cellulose wadding as blotters and incubated as above. The fungal colonies developing around the seeds incubated on both agar plates and filter papers were examined and the fungi were identified microscopically [15] and the level of incidence were recorded. To enumerate seedborne fungi in different seed parts, surface disinfected seeds were soaked in sterile water for four hours and then dissected aseptically into different parts (coat, endosperm, and embryo). Each seed part aseptically used for investigation of seedborne fungi as described above.

\subsection{Determination of Seed Moisture Content (SMC)}

Each seed sample (100 gm) was grounded in a blender and known weight of the resultant powder was dried in an oven for 24 hours at $105^{\circ} \mathrm{C}$, cooled in a desiccators and reweighed. The moisture content (MC) is expressed as percentage of the wet weight.

\subsection{Storage Experiment}

Seed samples (100 g each) were stored in four storage containers namely polyethylene bags, cotton cloth bags, tin cans and paper bags for six months at room temperature $\left(25 \pm 1^{\circ} \mathrm{C}\right)$ in the dark.

\subsection{Seed Analysis}

Vigor index (VI) of E. alata seeds were calculated Vigor index (VI) for each treatment was determined according to the following formula: $\mathrm{VI}=[$ mean of root length $(\mathrm{cm})$ + mean of shoot length $(\mathrm{cm})] \mathrm{X}$ percent seed germination. Nutritional values (total lipids, total nitrogen, ash content, and fiber content) of stored seeds were determined according to AOAC [11]. Aflatoxins $\left(B_{1}, B_{2}\right.$, and $\left.G_{1}\right)$ were extracted and cleaned up from storage seeds using chloroforme and cleaned using column chromatography according to AOAC [10]. Quantitative estimation of aflatoxins were carried spectrophotometrically [24] using standard aflatoxins (Sigma) as reference.

\subsection{Statistical Analysis}

For each experiment, the data were statistically analyzed using the analysis of variance procedure for completely randomized design. Treatment means were compared using the protected least significant difference (LSD) analysis according to Daniel [14].

\section{Results and Discussions}

In the present investigation, 31 seed samples of E. alata were analyzed to investigate their seedborne fungal flora by means of standard blotter and agar plate methods (Table 1 and Figure 1). As suggested by Abd_Allah and Hashem [2] the comprehensive outcome recommended

Table 1. Incidence (\%); case of isolations and occurrence remarks of seedborne fungal flora of $E$. alata following incubation on agar plate and blotter.

\begin{tabular}{|c|c|c|c|c|}
\hline \multirow{2}{*}{ Fungal species } & \multicolumn{2}{|c|}{ Incidence $(\%)$ of fungal species } & \multirow{2}{*}{ Cases of isolation (No.) } & \multirow{2}{*}{ Occurrence $^{Z}$} \\
\hline & Blotter test & Agar plate & & \\
\hline Alternaria alternata & 3.87 & 2.35 & 1 & $\mathrm{R}$ \\
\hline Alternaria sp. & 4.36 & 2.21 & 3 & $\mathrm{R}$ \\
\hline Aspergillus flavus & 14.65 & 16.37 & 42 & $\mathrm{H}$ \\
\hline Aspergillus nidulans & 2.75 & 0 & 4 & $\mathrm{~L}$ \\
\hline Aspergillus niger & 8.36 & 12.75 & 13 & M \\
\hline Aspergillus parasitcus & 18.52 & 21.18 & 37 & $\mathrm{H}$ \\
\hline Aspergillus sp. & 16.32 & 12.16 & 7 & $\mathrm{~L}$ \\
\hline Aspergillus terreus & 7.15 & 8.13 & 6 & $\mathrm{~L}$ \\
\hline Chaetomium globsum & 0.95 & 1.15 & 1 & $\mathrm{R}$ \\
\hline Cladosporium sp. & 1.78 & 0 & 2 & $\mathrm{R}$ \\
\hline Drechslera sp. & 1.07 & 0 & 1 & $\mathrm{R}$ \\
\hline Epicoccum sp. & 0.54 & 0.63 & 1 & $\mathrm{R}$ \\
\hline Fusarium moniliforme & 3.27 & 3.85 & 7 & $\mathrm{~L}$ \\
\hline Fusarium oxysporum & 2.96 & 2.56 & 6 & $\mathrm{~L}$ \\
\hline Penicillium sp. & 7.36 & 8.81 & 7 & $\mathrm{~L}$ \\
\hline Pythium sp. & 0.62 & 0.87 & 1 & $\mathrm{R}$ \\
\hline Rhizoctonia solani & 2.45 & 2.65 & 2 & $\mathrm{R}$ \\
\hline Rhizopus sp. & 0.61 & 0.83 & 4 & $\mathrm{R}$ \\
\hline Sclerotium bataticola & 1.54 & 1.35 & 2 & $\mathrm{R}$ \\
\hline Trichoderma sp. & 1.27 & 1.75 & 3 & $\mathrm{R}$ \\
\hline
\end{tabular}

Z: Out 31 E. alata seed samples. $\mathrm{H}=$ High occurrence ( $>24$ case); $\mathrm{M}=$ Moderate occurrence (from 12 to 24 cases); $\mathrm{L}=\mathrm{Low}$ occurrence (from 6 to 11 cases) and $\mathrm{R}=$ Rare occurrence $(<6$ cases $)$. 

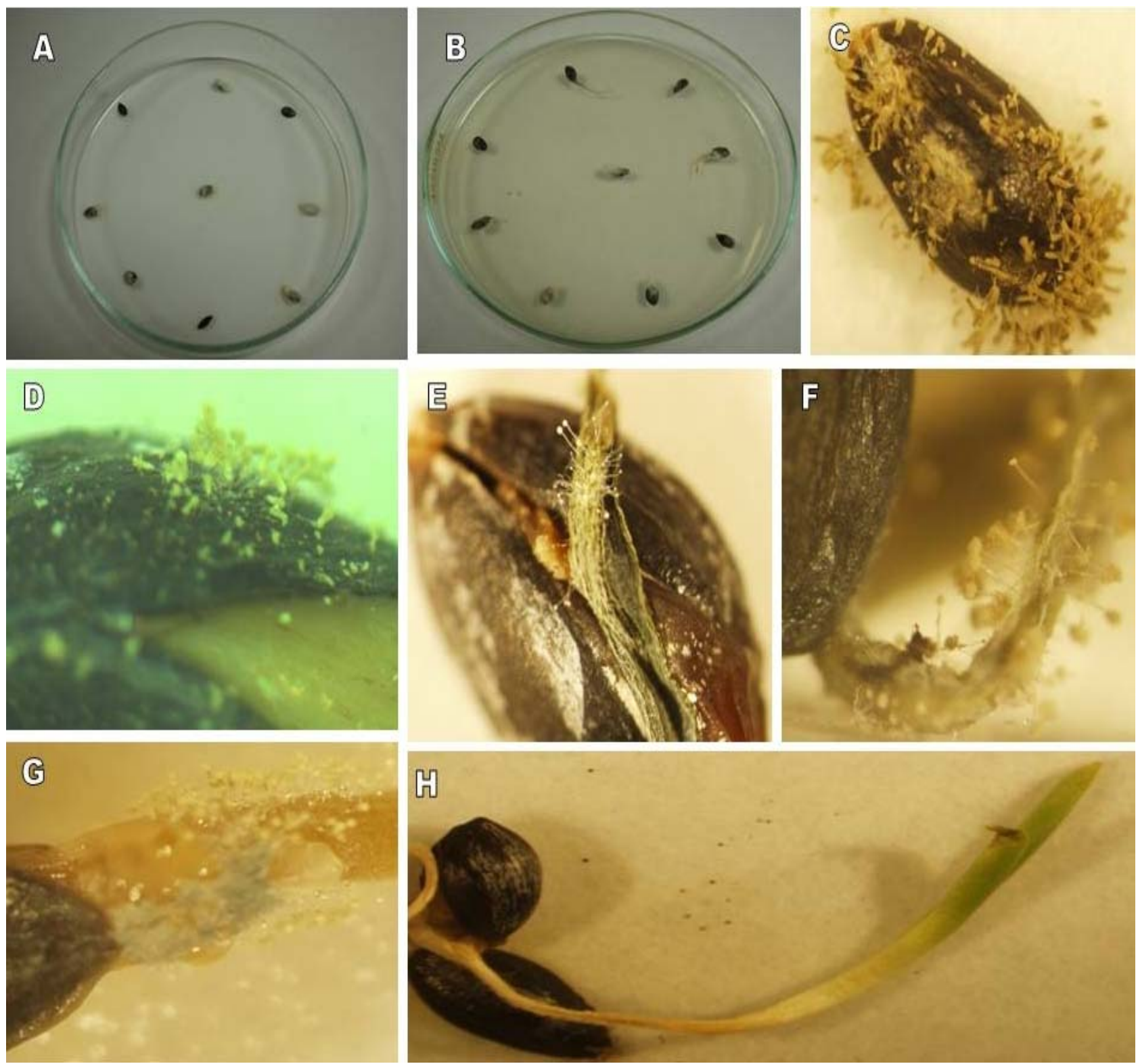

Figure 1. Detection of seedborne fungi associated with $E$. alata. A) Blotter and B) agar plate techniques used for enumeration of seedborne fungi. C-H) Stereo-microscopy of $E$. alata seeds acquaint the incidence of seedborne fungi on different seed parts.

that agar plate method was more conformable than moist paper (standard blotter) method in yielding more fungal flora (Table 1). The sequential incubation of seed samples yielded twenty fungal species belonging to thirteen genera, which are new to mycoflora of E. alata in Saudi Arabia (Table 1). The genes Aspergillus was the most predominant and represented by 6 species namely A. flavus, A. nidulans, A. niger, A. parasiticus, A. terreus and Aspergillus spp.. Aspergillus was followed by Fusarium (F. moniliforme and F. oxysporum) and Penicillium (Penicillium spp.), respectively. The other fungal genera
(Alternaria, Chaetomium, Cladosporium, Drechslera, Epicoccum, Pythium, Rhizoctonia, Rhizopus, Sclerotium, Trichoderma) were rare in their occurrence (Table 1). Up to our knowledge, this is the first investigation for seedborne mycoflora of E. alata especially in Saudi Arabia although the contamination of Saudi herbs with toxigenic mycoflora was reported [8]. Nevertheless, similar mycological studies for many other seeds showed that Aspergillus and Fusarium were the most common genera as seedborne fungi $[2 ; 16]$. The component plating of $E$. alata seeds showed that most prevalent fungi colo- 
nized seed coat (testa) followed by endosperm and embryo, respectively (Table 2). The highest colonization of storage aflatoxigenic molds such as A. flavus and A. parasiticus were in seed coat (21.97 and $11.53 \%$, respectively) followed by endosperm (12.93 and 10.37\%) and embryo (12.93 and 6.47\%) (Table 2). Similar mycological investigations showed the colonization of $A$. flavus and $A$. parasiticus in different seed parts involving embryo $[2 ; 28]$. Therefore, the role of seedborne fungi (especially aflatoxigenic) as one of the major source of seed deterioration during storage should be studied throughout integrated management to minimize the chances of further storage losses and field infection [30]. It was reported the alteration in moisture content (MC) of stored seeds depends up on the hygroscopic nature of storage containers [9]. Similarly, in our study both polyethylene bags and tin cans caused no any significant alteration in SMC (compared with the initial SMC), however cloth and paper bags caused significant decrement in SMC (Table 3). The retention of superior SMC recorded here by both polyethylene bags and tin cans is probably attributed to impervious nature of previous storage con- tainers compared with either cloth or paper bags [21].

There was a strong relationship between both storage periods and type of seed storage containers with seed health expressed as root depth, shoot height, percentage germination (Tables 4(a-d)). Prolonged storage periods were accompanied with decrease in vigor index ranged between slight and significant reduction depending upon the nature of storage containers. Such recorded decrease in vigor index (Seed germination, root depth and shoot height) strongly agrees with Basay et al., [12] and correlated with the alteration in SMC (Table 3) which act as a key factor influencing seed physical properties [27] and effectiveness of naturally seedborne fungal flora [2;9] which play vital role in diminution of viability and vigor of seeds [13]. The decrease in vigor index was significant with polyethylene storage container followed by tin cans, papers bags and cloth bags respectively (Table 4(d)). In the same connection, the polyethylene as impermeable storage container followed by tin cans, paper bags and cloth bags, respectively caused significant alteration in concentration of both $\mathrm{O}_{2}$ and $\mathrm{CO}_{2}$, which are the main cause of deterioration of agricultural products [18].

Table 2. Detection of seedborne fungi (Incidence [\%] of fungal species) in different seeds parts of E. alata using standard blotter method.

\begin{tabular}{lcccc}
\hline \multicolumn{1}{c}{ Fungal species } & \multicolumn{3}{c}{ Incidence (\%) of fungal species } \\
\cline { 2 - 5 } & Surface disinfected seeds & Seed Coat & Endosperm & Embryo \\
\hline Alternaria sp. & 12.16 & 3.56 & 2.78 & 5.82 \\
Aspergillus flavus & 42.71 & 12.93 & 6.35 & 21.97 \\
Aspergillus parasitcus & 28.37 & 11.53 & 10.37 & 6.47 \\
Fusarium moniliforme & 3.45 & 1.86 & 0.93 & 0.66 \\
Fusarium oxysporum & 4.63 & 2.06 & 2.17 & 0.4 \\
Sclerotium bataticola & 4.36 & 1.89 & 1.75 & 0.72 \\
Penicillium sp. & 0.8 & 0.61 & 0.19 & ND \\
Chaetomium sp. & 1.62 & 0.86 & 0.76 & ND \\
Drechslera sp. & 0.86 & 0.51 & 0.24 & 0.11 \\
Trichoderma $s p$. & 0.12 & 0.09 & 0.03 & ND \\
Pythium sp. & 0.92 & 0.61 & 0.31 & ND \\
\hline
\end{tabular}

${ }_{\mathrm{Z}} \mathrm{ND}$ : Not detected under the experimental conditions.

Table 3. Effect of various storage containers on seed moisture contentZ (SMC) [\%] of E. alata stored for different storage periods (months).

\begin{tabular}{cccccccc}
\hline \multirow{2}{*}{ Storage container } & \multicolumn{5}{c}{ Seed moisture content (SMC) [\%] of E. alata stored for different storage periods (months) } \\
\cline { 2 - 7 } & 1 & 2 & 3 & 4 & 5 & 6 & LSD at: 05 \\
\hline Polypropylene bag & 9.58 & 9.54 & 9.53 & 9.51 & 9.44 & 9.41 & 0.2512 \\
Cotton cloth bags & 8.20 & 8.11 & 7.91 & 7.50 & 6.67 & 6.07 & 9.39 \\
Tin cans & 9.63 & 9.57 & 9.50 & 9.45 & 9.43 & 7.41 & 0.1947 \\
Paper bags & 9.13 & 8.82 & 8.60 & 8.15 & 7.71 & 0.1955 \\
L. S. D. at: 05 & 0.2337 & 0.1175 & 0.2067 & 0.1935 & 0.2378 & 0.2566 \\
\hline
\end{tabular}

Z: Initial seed moisture content was $9.72(\%)$. 
Table 4-a. Effect of various storage containers on root depth $(\mathrm{cm})$ of germinating seeds of E. alata stored for different storage periods (months).

\begin{tabular}{cccccccc}
\hline \multirow{2}{*}{ Storage container } & \multicolumn{6}{c}{ Root depth $(\mathrm{cm})$ of germinating seeds of E. alata stored for different storage periods (months) } \\
\cline { 2 - 8 } & 1 & 2 & 3 & 4 & 5 & 6 & LSD. at: 05 \\
\hline Polypropylene bag & 15.30 & 14.33 & 12.77 & 11.73 & 9.97 & 8.27 & 0.4398 \\
Cotton cloth bags & 18.60 & 18.43 & 17.97 & 17.50 & 15.67 & 15.27 & 0.7383 \\
Tin cans & 17.53 & 17.03 & 16.17 & 15.90 & 15.07 & 13.80 & 0.8323 \\
Paper bags & 18.27 & 17.60 & 17.03 & 16.53 & 16.00 & 15.07 & 0.6134 \\
LSD at: 05 & 0.4280 & 0.4892 & 0.8117 & 0.4175 & 0.8044 & 1.0651 & \\
\hline
\end{tabular}

Table 4-b. Effect of various storage containers on shoot height $(\mathrm{cm})$ of germinating seeds of E. alata stored for different storage periods (months).

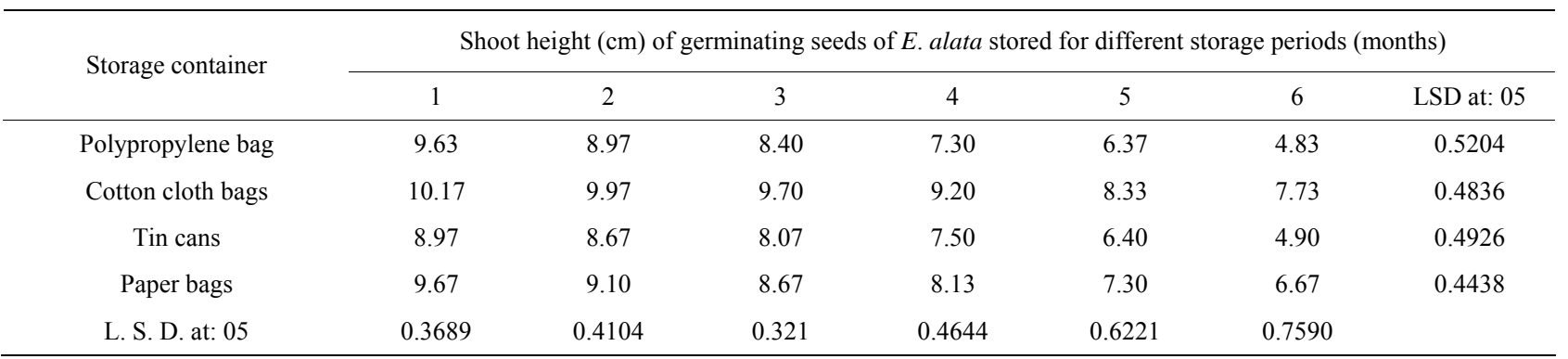

Table 4-c. Effect of various storage containers on percentage germination of E. alata stored for different storage periods (months).

\begin{tabular}{cccccccc}
\hline \multirow{2}{*}{ Storage container } & \multicolumn{7}{c}{ Percentage germination of E. alata stored for different storage periods (months) } \\
\cline { 2 - 8 } & 1 & 2 & 3 & 4 & 5 & 6 & LSD at: 05 \\
\hline Polypropylene bag & 61.30 & 59.93 & 57.20 & 53.70 & 51.20 & 43.33 & 1.9266 \\
Cotton cloth bags & 70.17 & 69.00 & 65.03 & 63.00 & 59.00 & 55.20 & 1.2275 \\
Tin cans & 65.23 & 63.20 & 60.57 & 56.87 & 52.27 & 46.53 & 1.3697 \\
Paper bags & 69.30 & 65.27 & 61.70 & 57.13 & 53.73 & 51.07 & 1.6294 \\
LSD at: 05 & 0.5040 & 0.9993 & 1.4174 & 2.1543 & 1.8938 & 2.2118 & \\
\hline
\end{tabular}

Table 4-d. Effect of various storage containers on seed vigor indexZ of E. alata stored for different storage periods (months).

\begin{tabular}{cccccccc}
\hline \multirow{2}{*}{ Storage container } & \multicolumn{7}{c}{ Vigor index of E. alata stored for different storage periods (months) } \\
\cline { 2 - 7 } & 1 & 2 & 3 & 4 & 5 & 6 & LSD at: 05 \\
\hline Polypropylene bag & 1528.41 & 1396.45 & 1210.73 & 1022.09 & 836.27 & 567.67 & 60.3480 \\
Cotton cloth bags & 2018.46 & 1959.60 & 1799.26 & 1682.10 & 1416.00 & 1269.60 & 83.1640 \\
Tin cans & 1728.68 & 1624.24 & 1467.73 & 1330.68 & 1121.99 & 870.17 & 73.3190 \\
Paper bags & 1935.78 & 1742.62 & 1585.69 & 1409.29 & 1251.99 & 1109.85 & 49.980 \\
L. S. D. at: 05 & 32.05 & 60.769 & 65.249 & 72.736 & 92.857 & 91.266 & \\
\hline
\end{tabular}

Z: Vigor index = Seed germination X [mean Root depth $(\mathrm{cm})+$ mean Shoot length $(\mathrm{cm})]$.

The effect of seed storage containers on aflatoxins production was investigated for seeds of many crops however, this approach does not provide a comprehensive view of the impact of range seeds. In our results, afla- toxins production were found to be inferior with employment of cloth bags followed by paper bags, tin cans and polyethylene bags respectively (Tables 5(a,d)). Such inhibition agrees with the findings of Paramawati et al., 
Table 5-a. Effect of different storage containers and storage periods (month) on the natural contamination of E. alata seeds with aflatoxin B1 ( $\mu \mathrm{g} / \mathrm{Kg}$ seed).

\begin{tabular}{|c|c|c|c|c|c|c|c|}
\hline \multirow{2}{*}{ Storage container } & \multicolumn{7}{|c|}{ Natural contamination with aflatoxin $\mathrm{B}_{1}(\mu \mathrm{g} / \mathrm{Kg}$ seed) of $E$. alata seeds stored for different storage periods (months) } \\
\hline & 1 & 2 & 3 & 4 & 5 & 6 & LSD at: 05 \\
\hline Polypropylene bag & 42.07 & 38.70 & 34.20 & 29.77 & 24.23 & 19.27 & 2.4825 \\
\hline Cotton cloth bags & 14.53 & 12.00 & 6.20 & 2.70 & 0.00 & 0.00 & 5.8834 \\
\hline Tin cans & 36.00 & 27.20 & 23.13 & 20.93 & 17.30 & 11.20 & 3.0896 \\
\hline Paper bags & 27.70 & 24.93 & 22.93 & 14.50 & 9.17 & 0.00 & 3.2088 \\
\hline L. S. D. at: 05 & 4.3322 & 2.6583 & 5.9746 & 5.7786 & 2.1357 & 2.1357 & \\
\hline
\end{tabular}

Table 5-b. Effect of different storage containers and storage periods (month) on the natural contamination of E. alata seeds with aflatoxin $B 2(\mu \mathrm{g} / \mathrm{Kg}$ seed).

\begin{tabular}{cccccccc}
\hline \multirow{2}{*}{ Storage container } & \multicolumn{6}{c}{ Natural contamination with aflatoxin $\mathrm{B}_{2}(\mu \mathrm{g} / \mathrm{Kg}$ seed) of E. alata seeds stored for different storage periods (months) } \\
\cline { 2 - 7 } & 1 & 2 & 3 & 4 & 5 & 6 & LSD at: 05 \\
\hline Polypropylene bag & 92.17 & 85.30 & 77.80 & 73.27 & 69.03 & 63.37 & 4.1764 \\
Cotton cloth bags & 45.07 & 34.93 & 28.63 & 18.50 & 11.17 & 9.50 & 3.5914 \\
Tin cans & 71.50 & 65.10 & 58.30 & 51.30 & 38.10 & 27.50 & 6.7281 \\
Paper bags & 77.17 & 66.27 & 55.67 & 46.87 & 37.43 & 24.27 & 4.9676 \\
L. S. D. at: 05 & 6.8605 & 4.6379 & 3.6884 & 6.4785 & 5.8013 & 3.2707 & \\
\hline
\end{tabular}

Table 5-c. Effect of different storage containers and storage periods (month) on the natural contamination of E. alata seeds with aflatoxin $\mathrm{G1}(\mu \mathrm{g} / \mathrm{Kg}$ seed).

\begin{tabular}{|c|c|c|c|c|c|c|c|}
\hline \multirow{2}{*}{ Storage container } & \multicolumn{7}{|c|}{ Natural contamination with aflatoxin $\mathrm{G}_{1}(\mu \mathrm{g} / \mathrm{Kg}$ seed) of $E$. alata seeds stored for different storage periods (months) } \\
\hline & 1 & 2 & 3 & 4 & 5 & 6 & LSD at: 05 \\
\hline Polypropylene bag & 35.87 & 30.03 & 26.77 & 21.50 & 18.40 & 11.23 & 2.5326 \\
\hline Cotton cloth bags & ND & ND & ND & ND & ND & ND & 0.00 \\
\hline Tin cans & 23.10 & 18.10 & 12.10 & 10.70 & ND & ND & 4.3153 \\
\hline Paper bags & 26.07 & 19.57 & 10.97 & 9.80 & 5.73 & ND & 2.6836 \\
\hline L. S. D. at: 05 & 5.0457 & 1.5258 & 1.3135 & 1.1019 & 4.6876 & 1.2105 & \\
\hline
\end{tabular}

ND: Not detected under the experimental conditions.

Table 5-d. Effect of different storage containers and storage periods (month) on the natural contamination of E. alata seeds with total aflatoxinsZ $(\mu \mathrm{g} / \mathrm{Kg}$ seed).

\begin{tabular}{|c|c|c|c|c|c|c|c|}
\hline \multirow{2}{*}{ Storage container } & \multicolumn{7}{|c|}{ Natural contamination with total aflatoxins ${ }^{\mathrm{Z}}(\mu \mathrm{g} / \mathrm{Kg}$ seed) of $E$. alata seeds stored for different storage periods (months) } \\
\hline & 1 & 2 & 3 & 4 & 5 & 6 & LSD at: 05 \\
\hline Polypropylene bag & 170.11 & 154.03 & 138.77 & 124.53 & 111.67 & 93.87 & 7.8536 \\
\hline Cotton cloth bags & 59.60 & 46.93 & 34.83 & 21.20 & 11.17 & 9.50 & 7.0388 \\
\hline Tin cans & 139.23 & 113.03 & 89.77 & 77.60 & 60.47 & 35.47 & 10.7660 \\
\hline Paper bags & 105.17 & 79.00 & 62.40 & 47.80 & 29.93 & 11.13 & 5.5776 \\
\hline
\end{tabular}

Z: Total aflatoxins (Sum. of B1 + B2 + G1).

[25]. It can explain in terms of the decrement alteration in SMC inferior requisite level for growth and aflatoxins production by seedborne fungi [2;9]. Data in our investigation (Tables 6 (a-d)) shows that prolongation of storage periods was accompanied with gradual deterioration in the biochemical aspects of seed such as lipids, ash, total nitrogen, and fiber contents. The employment of cloth bags followed by paper bags, tin cans and polyethylene bags respectively diminished such as sharpness in the deterioration of seed biochemical aspects (Tables 6 (a-d)). 
Table 6(a). Effect of different storage containers and storage periods (month) on nitrogen content (mg/g dry weight) of E. alata seeds.

\begin{tabular}{cccccccc}
\hline \multirow{2}{*}{ Storage container } & \multicolumn{6}{c}{ Nitrogen content (mg/g dry weight) of E. alata seeds stored for different storage periods (months) } \\
\cline { 2 - 7 } & 1 & 2 & 3 & 4 & 5 & 6 & LSD at: 05 \\
\hline Polypropylene bag & 32.48 & 30.06 & 28.6 & 28.37 & 27.48 & 26.50 & 0.1773 \\
Cotton cloth bags & 48.65 & 45.54 & 43.97 & 43.67 & 42.08 & 40.83 & 0.1002 \\
Tin cans & 39.65 & 35.86 & 32.88 & 31.31 & 30.76 & 31.073 & 0.1273 \\
Paper bags & 44.21 & 42.55 & 41.30 & 39.89 & 38.62 & 36.68 & 0.1119 \\
L. S. D. at: 05 & 0.1609 & 0.0981 & 0.1092 & 0.1084 & 0.0853 & 0.2270 & \\
\hline
\end{tabular}

Table 6(b). Effect of different storage containers and storage periods (month) on fiber content (\% of dry weight) of E. alata seeds.

\begin{tabular}{cccccccc}
\hline \multirow{2}{*}{ Storage container } & \multicolumn{7}{c}{ Fiber content (\% of dry weight) of E. alata seeds stored for different storage periods (months) } \\
\cline { 2 - 8 } & 1 & 2 & 3 & 4 & 5 & 6 & LSD at: 05 \\
\hline Polypropylene bag & 5.03 & 4.49 & 4.25 & 5.02 & 3.84 & 3.48 & 1.1738 \\
Cotton cloth bags & 5.36 & 5.09 & 4.96 & 4.84 & 4.76 & 4.61 & 0.8601 \\
Tin cans & 5.20 & 4.39 & 4.07 & 3.77 & 3.38 & 3.13 & 0.1723 \\
Paper bags & 5.27 & 4.93 & 4.66 & 4.37 & 4.94 & 4.12 & 0.3679 \\
LSD at: 05 & 0.2849 & 0.2246 & 0.2517 & 1.5158 & 1.1231 & 0.2852 & \\
\hline
\end{tabular}

Table 6(c). Effect of different storage containers and storage periods (month) on lipids content (\% of dry weight) of E. alata seeds.

\begin{tabular}{cccccccc}
\hline \multirow{2}{*}{ Storage container } & \multicolumn{6}{c}{ Lipids content (\% of dry weight) of E. alata seeds stored for different storage periods (months) } \\
\cline { 2 - 8 } & 1 & 2 & 3 & 4 & 5 & 6 & LSD at: 05 \\
\hline Polypropylene bag & 6.03 & 5.12 & 4.44 & 3.51 & 3.02 & 2.40 & 0.4421 \\
Cotton cloth bags & 7.63 & 7.21 & 7.03 & 6.86 & 4.29 & 6.50 & 0.4052 \\
Tin cans & 6.35 & 5.97 & 5.41 & 4.97 & 4.28 & 3.81 & 0.5560 \\
Paper bags & 7.20 & 6.83 & 6.40 & 6.06 & 5.83 & 5.50 & 0.3554 \\
LSD at: 05 & 0.5457 & 0.4259 & 0.4288 & 0.3882 & 0.3366 & 0.6253 & \\
\hline
\end{tabular}

Table 6(d). Effect of different storage containers and storage periods (month) on ash content (\% of dry weight) of E. alata seeds.

\begin{tabular}{cccccccc}
\hline \multirow{2}{*}{ Storage container } & \multicolumn{7}{c}{ Ash content (\% of dry weight) of E. alata seeds stored for different storage periods (months) } \\
\cline { 2 - 8 } & 1 & 2 & 3 & 4 & 5 & 6 & LSD at: 05 \\
\hline Polypropylene bag & 4.69 & 4.35 & 4.11 & 3.92 & 3.59 & 3.45 & 1.6900 \\
Cotton cloth bags & 6.52 & 6.40 & 6.25 & 6.20 & 6.09 & 5.89 & 3.5538 \\
Tin cans & 5.70 & 4.94 & 4.23 & 3.87 & 3.71 & 3.56 & 1.9654 \\
Paper bags & 6.22 & 5.921 & 5.67 & 5.40 & 5.18 & 4.91 & 0.7454 \\
LSD at: 05 & 4.1092 & 3.1294 & 1.3800 & 1.5175 & 0.6931 & 1.4413 & \\
\hline
\end{tabular}

Such results were in agreed with our data recorded previously concerning soybean seeds [17]. In this regard, the alteration in SMC due to the employment of different storage containers (Table 3) was the main cause of seedborne fungal activities [2;9] including production of hydrolytic enzymes such as proteinase [26], lipase [23] and lignocellulolytic enzymes [19] which were responsible for the biotic degradation of seed contents of protein, lipids and fiber [22]. Our results indicate that these biochemical events were correlated with maintenance of 
high germination rate during storage. The success of storage container to preserve seed viability recorded in this investigation is still limited and more studies through integrated seed management program to maintain healthy range plants in the grassland is needed hence production vital seeds are necessary for desert ecological maintenance. These will be considered in the forthcoming investigation.

\section{Acknowledgment}

We acknowledge Dr. Abeer Hashem, Bot. \& Microbiol. Department, Faculty of Science, King Saud University, Riyadh, Saudi Arabia for her excellent assistance in fungal identification that contributed in this success of this survey.

\section{REFERENCES}

[1] E. F. Abd_Allah, "Effect of a Bacillus subtilis Isolate on Southern Blight (Sclerotium rolfsii) and Lipid Composition of Peanut Seeds," Phytoparasitica, Vol. 33, No. 5, 2005, pp. 460-466.

[2] E. F. Abd_Allah and Abeer Hashem, "Seed Mycoflora of Lens esculenta and Their Biocontrol by Chitosan," Phytoparasitica, Vol. 34, No. 2, 2006, pp. 213-218.

[3] L. Abdallah, and M. Chaieb, "Water Status and Growing Phonology of a Saharan Shrub in North Africa," African Journal of Ecology, Vol. 1, No. 45, 2007, pp. 80-85.

[4] A. M. Abdelmonem, "Status of Seed Pathology and Seed Health Testing in Egypt," Seed Science \& Technology, Vol. 28, 2000, pp. 533-547.

[5] E. A. Abourashed, T. El-Alfy, I. A. Abir-Khan, and L. Walker, "Ephedra in Perspective-A Current Review," Phytother. Res. 17, 2003, 703-712.

[6] M.R. Al-Masri, "An in vitro evaluation of some drought-tolerant native range plants in terms of ruminal microbial nitrogen, microbial biomass and their fermentation characteristics utilizing a gas-production technique," Tropical Grasslands 4, 2007, 292-300.

[7] Wafaa A. Al-Taisan, A.A. Al-Qarawi and Moodi S. Alsubiee, "Effect of water stress by polyethylene glycol 8000 and sodium chloride on germination of Ephedra alata Decne seeds," Saudi journal of Biological Science 17, 2010, 253-257.

[8] Suaad S. Alwakeel, "The effect of mycotoxins found in some herbal plants on biochemical parameters in blood of female albino mice." Pakistan Journal of Biological Sciences 12 (8), 2009, 637-642.

[9] J.E. Amadi, and M.O. Adebola, "Effect of moisture content and storage conditions on the storability of garri," African Journal of Biotechnology 7(24), 2008, 4591-4594.

[10] Association of Official Analytical Chemists, "Official Methods of Analysis" (1 $11^{\text {th }}$ ed.), Section 26.019 (a), 429. AOAC, Washington, D.C, 1970.

[11] Association of Official Analytical Chemists "Official
Methods of analysis" (15 $15^{\text {th }}$ ed.). Washington , D.C, 1995.

[12] S. Basay, S.G. Okcu, and I. Demir, "Changes in germination percentages, protein and lipid contents of primed pepper seeds during storage," Acta Agriculturae Scandinavica 56, 2006, 138-142.

[13] M. Begum, and S. Lokesh, "Syngergistic effect of fungicides on the incidence of seed mycoflora of okra," International Journal of Botany 4(2), 2008, 24-32.

[14] W.W. Daniel, "Biostatistics: A foundation for Analysis in the Health Science" $4^{\text {th }}$ ed., John Wiley and Sons, New York, NY. pp. 292-293, 1987.

[15] K.H. Domsch, W. Gams, and T.H. Anderson, "Compendium of Soil Fungi”. Academic Press, London, 860 pp 1993.

[16] S. Figueroa, S. Centeno, M.A. Calvo, A. Rengel, and C. Adelantado, "Mycobiota and concentration of ochratoxin A in concentrated poultry feed from Venzuela," Pakistan Journal of Biological Sciences 12(7), 2009, 589-594.

[17] M.I. Ghonim, A.E.A. Ismail, and E.F. Abd_Allah, "Biological control of Aspergillus flavus in soybean seeds by atoxigenic A. flavus strain," Zazazig J. Agric Res., Vol. 26, No. 1, 1999, 27-35.

[18] P. Giorni, P. Battilani, A. Pietri, and N. Magan, "Effect of $\mathrm{a}_{\mathrm{w}}$ and $\mathrm{CO}_{2}$ level on Aspergillus flavus growth and aflatoxin production in high moisture maize post-harvest," International journal of Food Microbiology, Vol. 122, 2008, pp. 109-113.

[19] A. Gupte, S. Gupte, and H. Patel, "Ligninolytic enzyme production under solid state fermentation by white rot fungi," Journal of Scientific \& Industrial Research 66, 2007, 611-614.

[20] International Seed Testing Association [ISTA] "International rules for seed testing rules," Seed Sci. \& Technol. 24, 1996, 1-335.

[21] S.D. Malimath, and M.N. Merwade, "Effect of storage containers on seed storability of garden pea (Pisum sativum L.)," Karntaka J. Agri. Sci. 20(2), 2007, 384-385.

[22] J.E. Mellon, P.J. Cotty, and M.K. Down, “Aspergillus flavus hydrolysis: their roles in pathogenesis and substrate utilization," Appl. Microbiol. Biotechnol. 2007, 12011208.

[23] V. Mohanasrinivasan, P. Dhrisya, K.P. Dipinsha, C.M. Unnithan, K.M. Viswanath, and C.S. Devi, "Comparative study of the lipase yield by solid state and submerged fermentations using fungal species from biopharmaceutical oil waste," African Journal of Biotechnology 8(1), 2009, 73-76.

[24] J. Nabeny, and B.F. Nesbitt, "A spectophotometric method for determining the aflatoxins," Analyst 90, 1965, 155-160.

[25] R. Paramawati, P. Widodo, U. Budiharti, and dan Handaka, "The role of postharvest machineries and packaging in minimizing aflatoxin contamination in peanut," Indonesian journal of Agricultural Science 7(1), 2006, 15-19.

[26] A. Pekkarinen, L. Mannonen, B.L. Jones, and M.L. Niku-Paavola, "Production of proteases by Fusarium 
species grown on barley grains and in media containing cereal proteins," Journal of Cereal Science 31, 2000, 253-261.

[27] Z. Prochăzkovă, and L. Bezděčkova, "Effects of moisture content, storage temperature and type of storage bag on the germination and viability of stored European beech (Fagus sylvatica L.) seeds," Journal of Forest Science 54(7), 2008, 287-293.

[28] S. Rasheed, S. Dawar, and A. Ghaffar, "Location of fungi in groundnut seed," Pak J. Bot. 36(3), 2004, 663-668.

[29] S. S. Tag El-Din, A.M. Assaeed, and A.A. Al-Sheick, "Distribution of range plant communities as influenced by edaphic factors in Raudhat Khuraim," Egypt. J. Appl. Sci. 9(10), 1994, 69-82.

[30] M. Wagner, and N. Mitschunas, "Fungal effects on seed bank persistence and potential applications in weed biocontrol: a review," Basic and Applied Ecology 9, 2008, 191-203. 